\title{
BACTERIEMIA DURING ENDODONTIC TREATMENT IN RELATION TO THE TECHNIQUE OF BIOMECHANICAL PREPARATION: RANDOMIZED CLINICAL TRIAL
}

\author{
BACTERIEMIA DURANTE O TRATAMENTO ENDODÔNTICO EM FUNÇÃO DA TÉCNICA \\ DE PREPARO BIOMECÂNICO: ENSAIO CLÍNICO RANDOMIZADO
}

\author{
Adriane Tenório DOURADO ${ }^{1}$, Arnaldo de França CALDAS JUNIOR ${ }^{1}$, Diógenes Ferreira ALVES ${ }^{2}$, Creso Abreu FALCÃO ${ }^{3}$
}

1- DDS, MSc, PhD, Assistant professor, Department of Public Health Dentistry, Dental School, University of Pernambuco, UPE, Brazil. 2- DDS, MSc, PhD, Assistant professor, Department of Restorative Dentistry, Dental School, University of Pernambuco, UPE, Brazil.

3- MD, MSc, ssociate professor, Department of Clinical Medicine, School of Medical Sciences, University of Pernambuco, UPE, Brazil.

Corresponding address: Adriane Tenório Dourado - Rua Dona Magina Pontual, 224/101, Boa Viagem, Recife - PE, CEP: 51021-510 Phone: +55 (81) 33423922 - Fax: +55 (81) 32311118- Email: adriane@hotlink.com.br

Received: August 20, 2004 - Modification: December 02, 2004 - Accepted: March 02, 2005

\begin{abstract}
O bjective:The aim of this randomized clinical trial was to evaluate the frequency of bacteriemia during endodontic treatment, with comparison between two techniques for biomechanical preparation of the root canal system. Materials and methods: The sample comprised 50 patients aged 16 to 52 years, of both genders, which were divided into 2 groups with 25 patients each. Group I underwent biomechanical preparation by the step-back technique, and Group II was treated by the rotary technique with nickel-titanium instruments (K3). Patients were submitted to antisepsis of the oral cavity with chlorhexidine digluconate and three samples of blood were collected for blood culture: preoperatively, immediately after the biomechanical preparation and 10 minutes later. The significance level adopted was $5.0 \%$, and analysis was performed by descriptive and inferential statistics by means of the Fisher's exact test, Fisher-Freeman-Halton test and Student's t test. Data were analyzed on the Statexact and SPSS softwares. Results: All blood cultures achieved before and immediately after preparation were negative. On the other hand, with regard to the blood cultures collected 10 minutes after preparation, one (4\%) positive case was found for Group I. However, this difference was not statistically significant $(\mathrm{p}=0.50)$. Conclusion: The frequency of bacteriemia was low and observed just for Group I.

Uniterms: Bacteremia; Endocarditis, bacterial; Antibiotic prophylaxis; Root canal therapy.
\end{abstract}

\begin{abstract}
RESUMO
Q

bjetivo: O objetivo deste ensaio clínico randomizado foi avaliar a freqüência de bacteriemia durante o tratamento endodôntico comparando duas técnicas de preparo biomecânico do sistema de canais radiculares. Materiais e métodos: A amostra constou de 50 pacientes, com idade variando entre 16 e 52 anos e de ambos os sexos, sendo dividida em 2 grupos de 25 pacientes. No Grupo I, realizou-se o preparo biomecânico através da técnica escalonada com recuo progressivo programado, e, no Grupo II, por meio técnica rotatória, empregando instrumentos de níquel-titânio (K3). Os pacientes realizaram anti-sepsia da cavidade bucal com gluconato de clorexidina e foram realizadas três coletas de sangue para hemoculturas: no pré-operatório, imediatamente após o preparo biomecânico e 10 minutos depois. O nível de significância foi de 5,0\%, e foram utilizadas técnicas de estatística descritiva e inferencial através dos testes exato de Fisher, Fisher-Freeman-Halton e "T" de Student. A análise dos dados foi realizada através do programa Statexact e SPSS. Resultados: As hemoculturas tomadas antes e imediatamente após o preparo, foram todas negativas. Já nas hemoculturas, realizadas 10 minutos após o preparo, foi encontrado um caso (4\%) positivo no Grupo I. Esta diferença, entretanto, não foi estatisticamente significante ( $p=0,50)$. Conclusão: Concluiu-se que a freqüência de bacteriemia foi baixa e observada apenas no Grupo I.

Unitermos: Bacteriemia; Endocardite bacteriana; Antibioticoprofilaxia; Tratamento do canal radicular.
\end{abstract}




\section{INTRODUCTION}

Bacteriemia is characterized by the presence of microorganisms in the blood, and its intensity is directly related to the magnitude of the trauma, density of microbiota and presence of inflammation or infection ${ }^{1}$. Since the oral cavity has many microorganisms, any procedure causing discontinuity of the mucosa with consequent gingival bleeding may lead the patient to develop a temporary bacteriemia ${ }^{12,20}$ which may give rise to infectious endocarditis in patients at cardiac risk ${ }^{14}$.

The occurrence of bacteriemia after endodontic treatment depends on the type and limit of root canal instrumentation ${ }^{16}$. Some studies have found bacteriemia after endodontic procedures performed beyond the root apex ${ }^{1,3,6}$. However, there is still debate as to whether endodontic procedures may produce significant bacteriemia and trigger infectious endocarditis ${ }^{16}$.

Divergences were also observed between the guidelines of the American Heart Association (AHA) and of the British Society for Antimicrobial Chemotherapy (BSAC). The BSAC does not indicate the prophylaxis for non-surgical endodontic therapy, whereas the AHA indicates it for endodontic procedures beyond the tooth apex or surgical procedures, but not for the endodontic treatment within the root canal ${ }^{4,17}$. However, it is difficult to predict whether there will be intervention beyond the dental root during endodontic therapy, due to the unpredictable anatomy of the root apex and the difficulty to radiographically establish the working length, despite the aid of sophisticated devices for endodontic measurement.

The present study aimed to analyze, by means of a randomized clinical trial, the frequency of bacteriemia during endodontic therapy of teeth with pulp necrosis and radiographically visible periapical lesion submitted to intervention at the periapical region, with comparison between two techniques of biomechanical preparation, namely the step-back technique and a crown-down technique with rotary nickel-titanium instrument (K3).

\section{MATERIALS AND METHODS}

This double-blind randomized clinical trial was conducted at the Dental School of University of Pernambuco (FOP/ UPE) and at the University Hospital Oswaldo Cruz of University of Pernambuco (HUOC/UPE), Brazil. The study sample comprised patients aged 16 to 52 years, of both genders, in need of endodontic treatment of single-rooted teeth with pulp necrosis and radiographically visible periapical lesion. The subjects were achieved from the spontaneous demand of the Endodontics clinic and Integrated clinic of FOP/UPE and from the Dental Service of the City Hall of Camaragibe - PE. Exclusion criteria were as follows: 1) patients with systemic diseases in need of antibiotic prophylaxis; 2) individuals taking or having taken antibiotics less than 30 days before; 3 ) subjects with gingivitis in the same region of the tooth to be treated; 4) patients with positive blood cultures at the preoperative period; 5) subjects in need of endodontic retreatment.

Considering that a representative sample for evaluation of the presence of bacteriemia during endodontic therapy under the present study conditions would require a sample size larger than possible (thousands of cases - considering an a error of $5 \%$ and a prevalence of $4 \%$ ), and taking into account that this was a randomized clinical trial, the sample size was established at 50 patients.

The investigator was calibrated aiming to strictly control the operative sequence. Six patients were selected for that purpose, who were randomly divided into two groups. The investigator performed the treatments proposed for each group on these patients.

The sample was randomly divided, similarly to the pilot study, into two groups with 25 patients each. Utilization of a mechanical method for selection allowed a balanced randomization, i.e. equal numbers of patients for each treatment group. One endodontic treatment was performed per patient for each group, as follows: Group I comprised endodontic treatment of teeth with pulp necrosis and periapical lesion, by means of the step-back technique; Group II comprised endodontic treatment of teeth with pulp necrosis and periapical lesion by means of a crown-down technique with rotary nickel-titanium instruments (K3) for the biomechanical preparation.

The study design was approved by the Ethics Committee of University of Pernambuco - UPE, and all participants signed an informed consent form.

\section{Clinical and laboratory procedures}

A first blood sample was initially collected from the patients. Thereafter, the patients were submitted to antisepsis of the oral cavity by mouthrinsing with $25.0 \mathrm{~mL}$ of $0.12 \%$ chlorhexidine digluconate (Periogard - Colgate Palmolive / Kolynos do Brasil Ltda., Osasco, SP, Brazil) for one minute. Endodontic treatment was then initiated by the investigator (ATD), following the biosecurity protocols. All classical steps of endodontic therapy were conducted in the first session, except for root canal filling, which was performed in another session.

Group I was submitted to immediate neutralization of the septic-toxic content of the root canal, in crown-down direction, alternating with irrigation/suction/inundation with 5\% sodium hypochlorite (Farmácia Globo Ltda. - Recife, PE, Brazil). Preparation was performed by the step-back technique, from the apex to the crown, with utilization of hand instruments. In Group II, biomechanical preparation was accomplished in crown-down direction with utilization of rotary nickel-titanium instruments (K3 - SybronEndo, Glendora, CA, USA; handpiece Endo Pro - VK Driller Equipamentos Elétricos Ltda., São Paulo, SP, Brazil). The technique suggested for preparation with these instruments comprised initial selection of an instrument that fitted the cervical third of the root canal, followed by biomechanical preparation with instruments in decreasing order of size and taper, in crown-down direction. 
The biomechanical preparation in Groups I and II was performed up to $1 \mathrm{~mm}$ from the root apex, with utilization of an apical foramen instrument (IAF); apical patency was assured throughout the biomechanical preparation. After completion, endodontic treatment of the periapical region was conducted with a K file \#10 (Dentsply Maillefer, Ballaigues, Switzerland) introduced $1 \mathrm{~mm}$ beyond the apical foramen with gentle filing movements. Cleaning of the apical foramen should be passively accomplished at completion of the endodontic treatment with utilization of a precurved thin file (e.g. \#10) ${ }^{19}$.

Immediately after completion of the biomechanical preparation, ethylenediaminetetraacetic acid (EDTA) (Odacan - Dentsply Indústria e Comércio Ltda., Petrópolis, RJ, Brazil) was applied to the root canals of both groups and shaken for 3 minutes with an endodontic file. After this period, irrigation/suction was performed with 5\% sodium hypochlorite, followed by the second blood collection for the blood culture. Thereafter, a calcium hydroxide paste (Calen - S.S White Artigos Dentários Ltda., Rio de Janeiro, RJ, Brazil) was placed and temporary sealing was performed with glass ionomer cement (SS White Artigos Dentários Ltda., Rio de Janeiro, RJ, Brazil). After ten minutes, a third blood sample was collected for the blood culture.

\section{Blood culture}

Antisepsis of the area of venipunction (antecubital fossa) was performed with $70 \%$ alcohol allowed to dry for 1 minute before collection of the material for blood culture. A total of $5 \mathrm{~mL}$ of blood were collected from the antecubital vein, with utilization of sterile disposable syringe and needle. The blood collected was placed in a flask containing $45.0 \mathrm{~mL}$ of culture medium Brain Heart Infusion (BHI) (BAC- HEMOCULT Diagnósticos Microbiológicos Especializados - DME, Araçatuba, SP, Brazil), containing sodium polyanethol sulfonate (SPS), which is anticoagulant.
The flasks containing the material for blood culture were placed in a bacteriological oven at $37^{\circ} \mathrm{C}$ for 5 days, with reading to the presence of bacterial growth at every 24 hours. At the $3^{\text {rd }}$ day, aliquots were transferred to plates (blood agar, chocolate agar and Teague agar) containing solid culture media for observation of growth of bacterial colonies.

The plates were read after 24 hours. Whenever the blood culture was positive, the bacteria isolated were identified. When the result was negative, i.e. there was no bacterial growth, a second seeding was conducted at the $5^{\text {th }}$ day to check the result.

Bacterial identification was conducted by utilization of an automatic system (Rapid ID 32 STREP-API) (bioMérieux S.A., Marcy-I'Etoile, France), which identifies Streptococcus and similar microorganisms. This system was employed following the manufacturer's instructions.

Analysis of the data was performed by the softwares Statexact version 3.0 and SPSS (Statistical Package for Social Science) version 11.0. Data were depicted by descriptive statistics and inferential statistics by means of the Fisher's exact test, Fisher-Freeman-Halton test and Student's t test. Rejection of the null hypothesis was set at an a error of 0.05 .

\section{RESULTS}

Most subjects in the sample were of female gender (76\%), aged 16 to 26 years (52\%). The ages of both groups were similar ( $p=0.17$, with a mean age of 27.7 years for the total sample.

Table 1 reveals the homogeneity of the sample, i.e. the distribution of teeth was similar between both types of biomechanical preparation ( $\mathrm{p}=0.665)$.

The results of the first and second blood cultures (Table 2) were equal, i.e. there were 25 negative cases for both

TABLE 1- Distribution of the subjects according to the teeth and biomechanical preparation

\begin{tabular}{|c|c|c|c|c|c|c|}
\hline \multirow[b]{3}{*}{ Tooth } & \multicolumn{4}{|c|}{ Biomechanical preparation } & \multirow{2}{*}{\multicolumn{2}{|c|}{ Total }} \\
\hline & \multicolumn{2}{|c|}{ Hand } & \multicolumn{2}{|c|}{ Rotary } & & \\
\hline & $\mathbf{N}$ & $\%$ & $\mathbf{N}$ & $\%$ & $\mathbf{N}$ & $\%$ \\
\hline Maxillary right central incisor & 3 & 12.0 & 5 & 20.0 & 8 & 16.0 \\
\hline Maxillary right lateral incisor & 2 & 8.0 & 5 & 20.0 & 7 & 14.0 \\
\hline Maxillary right canine & 1 & 4.0 & 0 & 0.0 & 1 & 2.0 \\
\hline Maxillary left central incisor & 9 & 36.0 & 6 & 24.0 & 15 & 30.0 \\
\hline Maxillary left lateral incisor & 5 & 20.0 & 6 & 24.0 & 11 & 22.0 \\
\hline Mandibular left central incisor & 2 & 8.0 & 3 & 12.0 & 5 & 10.0 \\
\hline Mandibular left canine & 1 & 4.0 & 0 & 0.0 & 1 & 2.0 \\
\hline Mandibular left $1^{\text {st }}$ premolar & 1 & 4.0 & 0 & 0.0 & 1 & 2.0 \\
\hline Mandibular right $2^{\text {nd }}$ premolar & 1 & 4.0 & 0 & 0.0 & 1 & 2.0 \\
\hline Total & 25 & 100.0 & 25 & 100.0 & 50 & 100.0 \\
\hline
\end{tabular}

Fisher-Freeman-Halton test $(p=0.665)$ 
Group I, submitted to hand preparation, and Group II, submitted to rotary preparation. With regard to the third blood culture, there was one positive case (4\%) for the hand preparation group. However, this difference was not statistically significant $(\mathrm{p}=0.50)$.

Catalase test was negative and demonstrated the presence of streptococci; the automatic identification system revealed that the microorganism found in the only positive blood culture was mitis streptococci.

\section{DISCUSSION}

The main methodological difficulty for accomplishment of this study was the sample selection, due to the criteria for inclusion and exclusion of patients, which influenced the sample size.

There are no similar studies with this design in the literature; however, a Brazilian investigation employing a similar methodology ${ }^{18}$ included a smaller sample size, as well as other international studies ${ }^{1,6,8}$; and the only scientifically relevant study ${ }^{6}$ comprised a sample of only 26 patients.

Randomization was interesting to reduce the probability of influence on the results. The balanced randomization, i.e. groups with the same number of patients, was significant for the proportion of analyses ${ }^{13}$, as well as for the doubleblind nature of the study, i.e. the patients and examiners of the results were not aware of the type of treatment conducted for each participant, which allowed the reduction of the differential evaluation of the results, known of as observation or information bias ${ }^{15}$. Another important aspect was the randomization of treatment, as observed in Table 1.

Even though the $\mathrm{AHA}^{4}$ recommends the utilization of oral antiseptics as chlorhexidine before dental procedures, aiming to reduce the incidence and/or magnitude of bacteriemia, the potential of these agents to act as coadjutants or even as an alternative to antibiotics has not been extensively investigated. However, one study ${ }^{11}$ recommends such procedure. The results of the present study corroborate the recommendation of these authors, on the basis of the low percentage of bacteriemia. This preoperative procedure may be regarded as a positive aspect of the present methodology, since chlorhexidine had not been employed in any other previous study on the evaluation of bacteriemia in the field of Endodontics.

Reports on the bacteriemia produced by endodontic therapy only address the analysis of the working length, i.e. whether instrumentation was performed within or beyond the apical foramen, with no regard to the technique of biomechanical preparation of the root canal system or report of the technique employed. Some authors ${ }^{16}$ have highlighted the fact that crown-down instrumentation may reduce the microbial extension and frequency of bacteriemia by means of other variables, comparing a technique widely employed in Dentistry, namely the step-back technique, with a newer technique of modern Endodontics, the crown-down technique with utilization of rotary nickel-titanium instruments (K3).

Adoption of a single working length for both groups, i.e. at $1 \mathrm{~mm}$ from the radiographic apex with utilization of the apical foramen instrument (IAF), besides endodontic intervention $1 \mathrm{~mm}$ beyond the apical foramen at completion of the biomechanical preparation, aimed at making the endodontic therapy as similar as possible to the current recommendations of the literature for cases with chronic apical periodontitis and also to the clinical routine, because intervention beyond the apical foramen may not be clinically controlled. For example, a previous study ${ }^{3}$ has observed the occurrence of bacteriemia after strong manipulation beyond the apical foramen for 10 minutes. However, this is not a clinical procedure recommended by the literature. This study was also based on the persistence of controversies as to whether the working length may or not influence the frequency of bacteriemia. Previous studies ${ }^{1,3}$ have revealed that bacteriemia may be avoided when instrumentation is accomplished within the root canal, yet there may be bacteriemia if the periapical tissues are handled. However, other authors ${ }^{6,8}$ disagree with such findings on the basis of observation of bacteriemia even when the biomechanical preparation was performed within the apical foramen.

This investigation addressed only culture for aerobes and facultative anaerobes, since the bacteria most commonly related to acute infectious endocarditis secondary to dental procedures are Gram-positive facultative cocci, especially

TABLE 2- Distribution of the subjects according to the blood culture results

\begin{tabular}{|c|c|c|c|c|c|c|}
\hline \multirow[b]{3}{*}{ Blood culture } & \multicolumn{6}{|c|}{ Biomechanical preparation } \\
\hline & & \multicolumn{2}{|c|}{ Hand } & \multicolumn{2}{|c|}{ Rotary } & \multirow[b]{2}{*}{$\mathbf{p}^{*}$} \\
\hline & & $\mathbf{N}$ & $\%$ & $\mathbf{N}$ & $\%$ & \\
\hline \multirow[t]{2}{*}{ First } & Positive & 0 & 0.0 & 0 & 0.0 & 1.00 \\
\hline & Negative & 25 & 100.0 & 25 & 100.0 & \\
\hline \multirow[t]{2}{*}{ Second } & Positive & 0 & 0.0 & 0 & 0.0 & 1.00 \\
\hline & Negative & 25 & 100.0 & 25 & 100.0 & \\
\hline \multirow[t]{2}{*}{ Third } & Positive & 1 & 4.0 & 0 & 0.0 & 0.50 \\
\hline & Negative & 24 & 96.0 & 25 & 100.0 & \\
\hline
\end{tabular}

Fisher's exact test 
alpha-hemolytic viridans streptococci. On the other hand, Gram-negative aerobes account for less than 5\%, and anaerobes for less than $1 \%$ of the cases of infectious endocarditis ${ }^{10,12,18}$. One author ${ }^{10}$ highlights that, even though Gram-negative anaerobes seldom cause this disease, the reports of endocarditis related to these bacteria have increased because of the enhanced culture techniques.

The present study did not observe any case of bacteriemia in the blood samples collected immediately after biomechanical preparation of the root canal system for both study groups. On the other hand, one positive case was observed for the samples collected 10 minutes after completion of preparation, only for the group submitted to preparation by the step-back technique (Table 1). However, the difference between groups was not statistically significant $(p=0.50)$. The microorganism isolated from the positive culture was mitis streptococci, corroborating the outcomes of other authors ${ }^{7}$, who isolated this species after drainage of acute dentoalveolar abscesses. The present results were also similar to those observed in a previous study $^{8}$, which isolated viridans streptococci from the blood sample collected 10 minutes after completion of biomechanical preparation. Other investigators ${ }^{3,6,18}$ have also isolated this specie of microorganism, yet from the blood sample collected immediately after root canal instrumentation.

Investigations comprising endodontic treatment accomplished with utilization of rubber dam ${ }^{1,6,8}$ further demonstrate that the authors do not mention the exclusion of patients with gingivitis from the sample, since some studies have observed a direct relationship between procedures that cause gingival bleeding and bacteriemia ${ }^{4,5}$.

Another relevant aspect of the present study is that all endodontic procedures were conducted by a single operator. Even though other investigations do not mention this aspect, thus not allowing comparisons, this may be regarded as a positive aspect of this study, in order to avoid investigation or technical bias.

Bacteriemia associated to endodontic procedure is probably similar to that secondary to chewing or routine oral hygiene procedures ${ }^{9}$. The present study and previous investigations have demonstrated that the frequency of bacteriemia after handling of the periapical tissues is $\operatorname{low}^{1}$, especially when compared to other dental procedures ${ }^{2,3,8}$. This points the need to analyze the rationale of the AHA, which recommends the accomplishment of prophylaxis before endodontic therapy and does not indicate it before procedures such as infiltrative anesthesia, placement of rubber dam, removal of sutures and oral hygiene procedures. However, the AHA advises the professionals have to make a clinical decision about performing prophylaxis or not in cases of bleeding.

Finally, based on the outcomes of the present clinical trial, it may be concluded that dental professionals may employ either of the two techniques employed in the present study for root canal preparation of teeth with pulp necrosis and periapical lesion in patients at high or moderate cardiac risk, since there was no statistically significant difference between the study groups. The results further indicate the lack of need for antibiotic prophylaxis in these cases, yet the patient should have good oral health and the professional should follow the biosecurity protocols.

\section{CONCLUSION}

The frequency of bacteriemia during endodontic treatment was low. The frequency of bacteriemia observed for the endodontic treatment performed by hand biomechanical preparation was low and found in a single blood sample, collected 10 minutes after completion of root canal instrumentation. No bacteriemia was found for the cases treated by the rotary technique; there was no statistically significant difference between the outcomes of both study groups. Therefore, the hypothesis of this study was not accepted.

\section{REFERENCES}

1- Baumgartner JC, Heggers JP, Harrison JW. The incidence of bacteriemias related to endodontic procedures. I. Nonsurgical endodontics. J Endod. 1976;2:135-40.

2- Baumgartner JC, Heggers J P, Harrison J W. Incidence of bacteriemias related to endodontic procedures. II. Surgical endodontics. J Endod. 1977;3:339-402.

3- Bender IB, Seltzer S, Tashman S, Meloff G. Dental procedures in patients with rheumatic heart disease. Oral Surg Oral Med Oral Pathol. 1963;16:466-73.

4- Dajane AS, Taubert KA, Wilson W, Bolger AF, Bayer A, Ferrieri P, et al. Prevention of bacterial endocarditis: recommendations by the American Heart Association. J Am Med Assoc. 1997;277:1794-801.

5- Daly C, Mitchell D, Grossberg D, Highfield J, Stewart D. Bacteraemia caused by periodontal probing. Aust Dent J 1997; 42:77-80.

6- Debelian GJ, Olsen I, Tronstad L. Bacteriemia in conjuction with endodontic therapy. Endod Dent Traumatol. 1995;11:142-9.

7- Flood TR, Samaranayake LP, MacFarlane TW, McLennan A, MacKenzie D, Carmichael F. Bacteraemia following incision and drainage of dento-alveolar abscesses. Br Dent J. 1990;169:51-3.

8- Heimdahl A, Hall G, Hedberg M, Sandberg H, Söder PO, Tunér K, et al. Detection and quantitation by lysis-filtration of bacteriemia after different oral surgical procedures. J Clin Microbiol. 1990;28:2205-9.

9- Lavelle CLB. Is antibiotic prophylaxis required for endodontic treatment? Endod Dent Traumatol. 1996;12:209-14.

10- Lockhart PB. The risk for endocarditis in dental practice. Periodontol 2000. 2000;23:127-35.

11- Martin MV. Is there a link between tooth brushing and infective endocarditis? Int Dent J. 2003;53:187-90.

12- Pereira HT, Tarasconi JC, Pagnoncelli RM. Profilaxia da endocardite bacteriana em odontologia. Rev Odonto Ciênc. 1996;11:211-4. 
13- Petrie A, Bulman J S, Osborn J F. Further statistics in dentistry Part 3: Clinical trials 1. Br Dent J. 2002;193:495-8.

14- Rocha Barros VM, Ito IY, Azevedo RVP, Morello D, Rosatele PA, Filipecki LC. Bacteriemia após exodontia unitária, empregando dois métodos de anti-sepsia intra-bucal. Pesq Odontol Bras. 2000;14:19-24.

15- Schulz KF, Grimes DA. Blinding in randomized trials: hiding who got what. Lancet. 2002;359:696-700.

16- Seymour RA, Preshaw PM, Thomason JM, Ellis JS, Steele JG. Infective endocarditis, dentistry and antibiotic prophylaxis; time for a rethink? Br Dent J. 2000;189:610-6.

17- Simmons NA. Recommendations for endorcarditis prophylaxis. The Endocarditis Working Party for Antimicrobial Chemoterapy. J Antimicrob Chemother. 1993;31:437-8.

18- Simões W, Antoniazzi JH, Marques JLL. Bacteriemias durante o tratamento endodôntico. Rev Bras Odontol. 1995;52:44-7.

19- Soares IJ, Goldberg F. Endodontia: técnicas e fundamentos. Porto Alegre: Artmed; 2001.

20- Titsas A, Ferguson MM. Concepts for the prophylaxis of infective endocarditis in dentistry. Aust Dent J. 2001;46:220-5. 